Review

\title{
Serum Magnesium Levels in Patients with Obstructive Sleep Apnoea: A Systematic Review and Meta-Analysis
}

\author{
Zahraa Al Wadee*, Soo Liang Ooi (D)*, Sok Cheon Pak ${ }^{(\mathbb{D})}$
}

School of Dentistry and Medical Sciences, Charles Sturt University, Panorama Avenue , Bathurst, NSW 2795, Australia

- The first two authors contributed equally to this work.

*Correspondence: spak@csu.edu.au; Tel: 61-2-6338-4952; Fax: 61-2-6338-4993.

\begin{abstract}
Purpose: Obstructive sleep apnoea (OSA) affects patients' quality of life and health. Magnesium $(\mathrm{Mg})$ is an essential mineral and a potent antioxidant. $\mathrm{Mg}$ deficiency can worsen oxidative stress caused by sleep deprivation or disorders. The impact of OSA on serum $\mathrm{Mg}$ levels and its health consequences remain unclear.
\end{abstract}

Methods: This study systematically reviewed clinical studies investigating the serum $\mathrm{Mg}$ levels of OSA patients and the potential relationships with other biomarkers.

Results: Six articles were included for qualitative synthesis; five were used in quantitative analysis. Two out of four studies that compared OSA patients to healthy controls found them to have significantly lower serum Mg levels. Our meta-analysis with three studies shows that patients with OSA had significantly lower serum Mg with an effect size of -1.22 (95\% CI: $2.24,-0.21)$. However, the mean serum $\mathrm{Mg}$ level of OSA patients $(\mathrm{n}=251)$ pooled from five studies $(1.90 \mathrm{mg} / \mathrm{dL}, 95 \% \mathrm{CI}: 1.77,2.04)$ does not differ significantly from the normal range. OSA severity appears to affect serum $\mathrm{Mg}$ negatively. Serum $\mathrm{Mg}$ levels generally improve after treatment, coincide with the improvement of OSA severity. Low serum Mg levels correlate with worsening of cardiovascular risk biomarkers of C-reactive protein, ischaemia-modified albumin, and carotid intima-media thickness. The serum $\mathrm{Mg}$ levels also potentially correlate with biomarkers for lipid profile, glucose metabolism, calcium and heavy metals.

Conclusions: Sleep deprivation appears to deplete Mg levels of OSA patients, making them at risk of $\mathrm{Mg}$ deficiency, which potentially increases systemic inflammation and the risk of cardiovascular and metabolic diseases.

Keywords: Obstructive sleep apnoea; intermittent airway obstruction; sleep disorder; magnesium; micronutrient deficiency; metabolic risk factor 


\section{Introduction}

Human beings spend approximately one-third of their lives sleeping. Adequate and restful sleep is essential for maintaining optimal health. Sleep deprivation resulting from functional disorders can lead to poor quality of life and morbidity. Obstructive sleep apnoea (OSA) is characterised by frequent episodes of partial or complete upper airway collapse during sleep. The disruption of respiratory airflow can occur when there is a physical blockage to the airways caused by the tongue and surrounding soft tissue structures falling back to the throat due to gravity and muscle relaxation. These episodes result in complete or partial reduction of airflow and recurrent arousals from sleep $[1,2]$.

The pathogenesis of OSA is multifactorial, with a combination of both anatomical and non-anatomical causes. OSA patients often have pharyngeal anatomical abnormalities such as narrow pharyngeal airway, increased airway length, and specific pharyngeal lumen shapes. Non-anatomical factors, such as impaired pharyngeal dilator muscle function, low respiratory arousal threshold, and unstable control of breathing, also contribute to upper airway collapse and frequent arousal during sleep [1]. Individuals with OSA may experience symptoms such as snoring, excessive daytime sleepiness, morning headache, fatigue, non-refreshing sleep, nocturia, irritability, and memory loss [1,3]. Without proper management, OSA can severely impact their health-related quality of life.

Magnesium $(\mathrm{Mg})$ is an essential mineral for biochemical activities in the human body and is involved in many enzyme systems as a cofactor [4]. In mammals, cells regulate $\mathrm{Mg}$ content through the controlled transport and buffering mechanisms maintained by various hormones and cellular messengers. A dynamic relationship exists between the changes in the total content of $\mathrm{Mg}$ transported across cells and within cellular compartments through the effect of hormones and agents [5]. Hence, it is essential to maintain adequate cellular $\mathrm{Mg}$ level for optimal enzyme function in energy metabolism and neurotransmitter synthesis [6]. Mechanisms associated with impaired $\mathrm{Mg}$ regulation can be related to common chronic diseases, which can also be affected by dietary intake. Current dietary guidelines recommend a daily intake of 310$420 \mathrm{mg}$ of $\mathrm{Mg}$ to maintain health and lower the risk of inflammatory diseases [7]. However, in Australia, $37 \%$ of males and $34 \%$ of females did not meet the daily requirements for $\mathrm{Mg}$ [8] and maybe at risk of $\mathrm{Mg}$ deficiency. Signs of $\mathrm{Mg}$ deficiency are nonspecific, which may include low potassium and calcium levels, elevated blood pressure, neuromuscular irritability, muscle cramps and spasms, as well as mental disturbances such as depression, confusion, agitation, hallucinations [9].

Serum $\mathrm{Mg}$ level is widely used in clinical practice to assess the total body $\mathrm{Mg}$ status. The commonly used reference range for serum $\mathrm{Mg}$ level is between 1.82 to 2.30 $\mathrm{mg} / \mathrm{dL}(0.75-0.95 \mathrm{mmol} / \mathrm{L})$ based on the 1974 National Health and Nutrition Examination Survey 1 (NHANES 1) [10]. This range was derived from the central $95^{\text {th }}$ percentile of serum Mg levels in 15,820 healthy individuals aged 18-74 with an estimated mean of 2.07 $\mathrm{mg} / \mathrm{dL}(0.85 \mathrm{mmol} / \mathrm{L})$. Such a reference range does not truly reflect the relationship between serum Mg levels and clinical outcomes. Hence, having a level of serum $\mathrm{Mg}$ within the reference range does not rule out the possibility of subclinical or chronic latent deficiencies [11].

Nonetheless, serum $\mathrm{Mg}$ remains a practical and valuable biomarker for assessing $\mathrm{Mg}$ status when used in combination with 24-hr urinary $\mathrm{Mg}$ excretion and dietary $\mathrm{Mg}$ intake [10]. A recent evidence-based recommendation proposed that the clinical cut-off of serum $\mathrm{Mg}$ should be at $2.07 \mathrm{mg} / \mathrm{dL}$ $(0.85 \mathrm{mmol})$. The suggested healthy range of serum $\mathrm{Mg}$ level is between 2.07 to 2.30 $\mathrm{mg} / \mathrm{dL}(0.85-0.95 \mathrm{mmol} / \mathrm{L})$. Anyone with 
serum $\mathrm{Mg}<2.07 \mathrm{mg} / \mathrm{dL}$ is at risk of moderate to severe $\mathrm{Mg}$ deficiency and an increased risk of chronic conditions such as diabetes mellitus [11].

Deficiency in $\mathrm{Mg}$ intake from dietary and subsequent $\mathrm{Mg}$ inadequacy have been associated with many chronic conditions, including cardiovascular diseases [12], metabolic syndrome [13], diabetes mellitus [14], and obesity [15]. Similarly, being overweight or obese and metabolic syndrome also increase the risk of having moderate to severe OSA [16], which is further linked to hypertension, diabetes, coronary artery disease, heart failure and cardiac arrhythmias [17]. Hence, $\mathrm{Mg}$ deficiency and OSA share common metabolic comorbidities as $\mathrm{Mg}$ is a cofactor in many fundamental functions, including energy production, glycaemic control, myocardial contraction, and blood pressure [18]. Notwithstanding, the link between $\mathrm{Mg}$ level and OSA remains poorly understood.

This study aims to systematically search and review the published literature to assess the relationship between serum $\mathrm{Mg}$ and OSA to answer the following research questions. In adult patients diagnosed with OSA: (1) Do they have lower than normal serum $\mathrm{Mg}$ levels? (2) Are they at risk of Mg deficiency based on their serum Mg levels? (3) Are there any correlations between serum $\mathrm{Mg}$ level with OSA severity? (4) Do their serum Mg levels correlate with other metabolic, nutritional, inflammatory, or cardiac markers?

\section{Materials and Methods}

\subsection{Literature search}

We conducted systematic searches on PubMed, EBSCOhost (Health), ProQuest, and Web Of Science between May and June 2020 and again from November to December 2020. The keywords used in the searches are: (magnesium) AND ((obstructive sleep apnoea) OR (obstructive sleep apnea) OR (sleep apnoea) OR (sleep apnea) OR (intermittent airway obstruction) OR (sleep disordered breathing)). We also manually searched the references of the full-text articles downloaded during the review process. The searches were conducted by two authors (ZAW \& SLO) independently. Search results were downloaded and imported in EndNote X8.2 to remove duplicates, screen and manage articles.

\subsection{Selection criteria}

Criteria of inclusion: (1) human study, (2) published in English, (3) participants were adults ( $\geq 18$ years old), (4) diagnosed with OSA with apnoea-hypopnoea index (AHI) $>5 /$ hour, (5) the study measured serum $\mathrm{Mg}$ levels before any intervention. Two authors (ZAW \& SLO) conducted study selection, and the third author reviewed the results (SCP).

\subsection{Data extraction and meta- analysis}

We extracted the following information from the study: first author, year of publication, country, participants' characteristics, sample size and gender distribution, study design, mean serum $\mathrm{Mg}$ in $\mathrm{mg} / \mathrm{dL}$ with the standard deviation (SD) of the OSA patients and controls (if any), and relevant findings of the study.

For studies that compared the serum $\mathrm{Mg}$ of OSA patients to healthy controls, the sample sizes of OSA and control groups and the standardised mean difference (Hedge's g) with SDs of both groups were combined for meta-analysis. We also performed a metaanalysis of single means by pooling the sample sizes, mean serum Mg levels and SDs of the cross-sectional (or baseline) measurements across all studies. All analyses were done based on published data only. For studies that did not report the SDs, the p-value or $95 \%$ confidence interval was used for estimation using the RevMan Calculator [19]. The data from each study were weighted such that studies with less variance or a larger sample size contributed more heavily to the 
overall estimate of means under the inverse variance method. The heterogeneity between studies was examined using $\mathrm{I}^{2}$ statistics, with $25 \%, 50 \%$, and $75 \%$ values reflecting low, moderate, and high heterogeneity. The random effects model was adopted for the meta-analysis to compensate for the heterogeneity across studies. We investigated the source of heterogeneity through the elimination of studies. The 'meta' and 'metafor' packages in R (version 4.03) were used to perform the meta-analysis and display results. The student's t-test was used for testing the significant difference between the pooled mean and the known population mean with the significance level set at 0.05. ZAW and SLO performed data extraction followed by meta-analysis, and SCP reviewed the results.

\subsection{Assessment of methodological quality}

The study adopted the Quality Assessment Tool for Case-Control, Observational Cohort and Cross-Sectional Studies published by the National Institute of Health for quality assessment of the included studies [20]. All authors rated the studies independently. Differences in rating were resolved through consensus after discussion.

\section{Results}

\subsection{Search results}

The literature search flow diagram is depicted in Figure 1. Our systematic searches yielded 176 unique records after the removal of duplicates. Following an initial screening, the full text of eleven entries was sourced and assessed for eligibility. Five articles were excluded with reasons (Figure 1). Six studies [21-26] are included in this systematic review, and five in the meta-analysis.

Table 1 shows a summary of the characteristics of these studies. A total of 312 OSA patients participated in these studies, with male patients out-numbered female 2.61 to 1 , based on the gender split reported by five of the studies. The pooled mean age is 49.24 \pm 8.94 (mean \pm SD) across 279 participants (one study did not report the mean age).

\subsection{Serum $\mathrm{Mg}$ levels and risk of $\mathrm{Mg}$ deficiency}

\subsubsection{Comparing to healthy controls}

Only four out of the six studies compared the serum Mg levels of OSA patients to healthy controls. At the time of diagnosis, participants in the OSA group $(\mathrm{N}=68)$ in the study by Karamanli et al. [23] showed an average $\mathrm{Mg}$ level of $1.71 \pm 0.21 \mathrm{mg} / \mathrm{dL}$. These levels were significantly lower than the controls $(\mathrm{N}=30)$ matched for age, sex and BMI, which showed healthy levels of mean serum $\mathrm{Mg}$ serum at $2.19 \pm 0.36 \mathrm{mg} / \mathrm{dL} \quad(\mathrm{p}<0.0001)$. These findings were similar to that of Xu et al. [24], where patients with OSA $(\mathrm{N}=33,1.71 \pm 0.21$ $\mathrm{mg} / \mathrm{dL}$ ) had serum $\mathrm{Mg}$ levels significantly lower $(\mathrm{p}=0.021)$ than those in the control group $(\mathrm{N}=33,2.19 \pm 0.36 \mathrm{mg} / \mathrm{dL})$. Furthermore, 23 patients $(69.7 \%)$ in the OSA group demonstrated hypomagnesemia.

In contrast, in the case-control study by Cakir et al. [25], there were no significant differences ( $p>0.05)$ in mean serum $\mathrm{Mg}$ levels between the OSA group $(\mathrm{N}=70,2.0 \pm 0.12$ $\mathrm{mg} / \mathrm{dL})$ and healthy controls $(\mathrm{N}=30$, $2.04 \pm 0.19 \mathrm{mg} / \mathrm{dL})$. The participants' characteristics in this study may have influenced the results as they were male smokers. Furthermore, seven of the OSA patients and three control subjects had diabetes, and one participant in the OSA group was hypertensive. These results were in contrast to Asker et al. [21], which evaluated serum levels of trace metals in OSA patients. The study showed that participants with OSA $(n=61)$ had significantly higher levels of trace minerals, including $\mathrm{Mg}$ and heavy metals, than in healthy controls $(n=36)(p<0.001)$. It is important to note that there were inconsistencies in the unit measurement of $\mathrm{Mg}$ in the reported findings of Asker et al. [21]. The mean for $\mathrm{Mg}$ for both the control group and OSA group was in micrograms per decilitre $(\mu \mathrm{g} / \mathrm{dL}) \quad(11.20 \pm 7.22 \quad$ and 
14.13 \pm 4.88 , respectively). When converting these numbers to milligram per/ decilitre $(\mathrm{mg} / \mathrm{dL})$, the standard unit of comparison in our report, the measurements were 0.01413 $\mathrm{mg} / \mathrm{dL}$, which were too low for both groups. A request for clarification to the author of this study was made. However, no response was received. The discrepancy may have resulted from errors in the recording unit of measurement. Hence, we assumed the mean $\mathrm{Mg}$ levels for OSA patients in this study to be $1.413 \mathrm{mg} / \mathrm{dL}$ and $1.120 \mathrm{mg} / \mathrm{dL}$ the healthy controls for the subsequent meta-analysis.

\subsubsection{Meta-analysis - Effect size}

A meta-analysis of the effect sizes (Hedge's g) of OSA on the serum Mg levels compared to healthy controls with data from four studies is shown as a forest plot in Figure 2a. Due to the high heterogeneity $\left(\mathrm{I}^{2}=95 \%\right)$ a random effects model was used. The overall effect is estimated at -0.79 (95\% CI: $-1.88,0.29)$, but it is not statistically significant. One study, namely Asker et al. [21], skews the overall effect. Since the unit of measurement for $\mathrm{Mg}$ levels was questionable in Asker et al. [21] and the controls in this study also suffered from hypomagnesemia $(1.120 \mathrm{mg} / \mathrm{dL})$ and might not represent the healthy population, this study was eliminated for sensitivity analysis. The new analysis yields a statistically significant effect size of -1.22 (95\% CI: $-2.24,-0.21$ ), as shown in Figure 2b. This analysis supports the alternate hypothesis that OSA patients' mean serum $\mathrm{Mg}$ levels are lower than those of the healthy matching controls.

\subsubsection{Meta-analysis - Pooled mean}

A meta-analysis of the mean serum $\mathrm{Mg}$ levels of all included studies after the exclusion of Asker et al. [22] is shown as a forest plot in Figure 3. Due to the high heterogeneity $\left(\mathrm{I}^{2}=97 \%\right)$ a random effects model was used. The pooled mean of the meta-analysis is 1.90 (95\% CI: 1.77, 2.04) mg/dL. Investigation of heterogeneity by eliminating studies found heterogeneity did not reduce with the exclusion of any single study, even with the study which has apparent dissimilar sample (Jiao et al. [22]). Heterogeneity only reduced to moderate $\left(\mathrm{I}^{2}=36 \%\right)$ after eliminating three studies with the lowest means [21,23,24] with participants consisting of mostly hypomagnesemia OSA patients. The sizeable statistical heterogeneity across studies can be due to the inherently diverse characteristics of the OSA patient population. In any case, the pooled mean of $1.90 \mathrm{mg} / \mathrm{dL}$ (95\% CI: 1.77 , 2.04) does not differ significantly from the reference range of normal healthy population (mean=2.07 mg/dL, 95\% CI: 1.82-2.30). Hence, results from the present analysis do not support the hypothesis that OSA patients have lower than normal serum $\mathrm{Mg}$ levels in general. However, with the $95 \%$ CI of the pooled mean below the healthy cut-off value of $2.07 \mathrm{mg} / \mathrm{dL}$ as suggested by Costello et al. [11], we can conclude these patients are at risk of $\mathrm{Mg}$ deficiency.

\subsection{Serum Mg and OSA severity}

\subsubsection{Serum Mg and AHI}

When comparing patients with different OSA severities, Zota et al. [26] showed that those with severe OSA (AHI $\geq 30, \quad \mathrm{~N}=23$ ) had reduced serum $\mathrm{Mg}$ levels when compared to those with moderate OSA $(15 \leq \mathrm{AHI}<30$, $\mathrm{N}=18$ ), but the mean difference (MD) was not statistically significant $(\mathrm{MD}=0.19, \mathrm{p}=0.1)$. It is worth noting that comorbidities of hypertension, impaired fasting glucose, dyslipidemia were common among moderate to severe OSA patients recruited in this study.

Similarly, Karamanli et al. [23] reported no significant difference in serum $\mathrm{Mg}$ between patients with moderate OSA and those with severe symptoms. However, the mean serum $\mathrm{Mg}$ level of patients with mild OSA was significantly higher than those in the severe group $(1.84 \pm 0.1$ vs. $1.67 \pm 0.26 ; p=0.003)$ [23]. Additionally, in multiple regression analysis, Karamanli et al. [23] found serum Mg level was still significantly associated with AHI ( $\beta=-0.03, p=0.01$ ) after adjusting for age, gender, and BMI. 


\subsubsection{Before and after treatment}

The severity of OSA symptoms generally improved after therapy. Two studies measured the serum $\mathrm{Mg}$ of OSA patients before and after treatment. In an observation study by Jiao et al. [22], postoperative blood $\mathrm{Mg}$ levels significantly increased in OSA patients $(\mathrm{N}=39)$, six to 12 months after Rouxen-Y gastric bypass (RYGB) for weight loss, compared to pre-intervention levels $(2.04 \pm 0.17 \mathrm{mg} / \mathrm{dL}$ vs. $2.19 \pm 0.17 \mathrm{mg} / \mathrm{dL}$, $\mathrm{p}<0.05)$. The RYGB surgery also improved AHI severity ratings with a MD of 12.64 (95\% CI: -16.81 to $-8.4, \quad \mathrm{p}<0.001)$. However, the improvement in AHI appeared uncorrelated with serum Mg based on Pearson and Spearman correlation analysis. This study, however, suffered from a high drop-out rate, with 15 out of the initial 54 recruits $(27.7 \%)$ not completing the study.

In the cross-sectional study of Xu et al. [24], 22 out of the 33 OSA patients were followed up after three months of continuous positive airway pressure (CPAP) treatment. An improvement in serum $\mathrm{Mg}$ levels was observed with a mean of $2.02 \pm 0.25 \mathrm{mg} / \mathrm{dL}$, which was significantly higher $(p<0.001)$ than the baseline value of $1.71 \pm 0.21 \mathrm{mg} / \mathrm{dL}$. Pearson correlation between serum $\mathrm{Mg}$ and AHI was almost statistically significant $(\mathrm{r}=-$ $0.302, \mathrm{p}=0.056$ ). Nevertheless, their postCPAP mean serum $\mathrm{Mg}$ remained significantly lower than the control group's baseline value (vs. $2.19 \pm 0.36 \mathrm{mg} / \mathrm{dL} ; \quad \mathrm{p}=0.05$ ). In multivariate logistic regression analysis, serum $\mathrm{Mg}$ levels were shown to be a protective factor for OSA severity, with participants having $\geq 1.98 \mathrm{mg} / \mathrm{dL}$ less likely to have severe OSA than those with serum $\mathrm{Mg}$ level below $1.98 \mathrm{mg} / \mathrm{dL}$ (Odd Ratio= 0.54, 95\% CI: 0.38-0.88; $\mathrm{p}=0.006$ ) [24].

\subsection{Serum Mg and biomarkers}

\subsubsection{Lipid profile}

Two studies reported the correlation between serum $\mathrm{Mg}$ levels and lipid metabolism indices. Using Spearman's rho tests, Asker et al. [21] showed that serum $\mathrm{Mg}$ was positively correlated with triglycerides $(\mathrm{r}=0.340$, $\mathrm{p}=0.003$ ), negatively correlated with highdensity lipoproteins (HDL) ( $\mathrm{r}=-0.244$, $\mathrm{p}=0.003)$, while correlations with total cholesterol and low-density lipoproteins (LDL) were not significant. Çakır et al. [25], on the other hand, did not detect any statistically significant Spearman correlations between serum $\mathrm{Mg}$ and any of the lipid biomarkers.

\subsubsection{Glucose metabolism}

Jiao et al. [22] reported that serum Mg levels appeared to increase along with improved blood glucose control after RYGB. However, no significant correlation was found between the AHI and fasting glucose and insulin before and after RYGB surgery. In contrast, Çakır et al. [25] found evidence that supported the association between serum $\mathrm{Mg}$ and glucose metabolism biomarkers, which include fasting serum glucose, serum fasting insulin, and homeostatic model assessmentinsulin resistance. These three biomarkers were significantly different between OSA patients and controls $(\mathrm{p}=0.004, \mathrm{p}=0.003$, $\mathrm{p}<0.001$, respectively). Meanwhile, only fasting serum glucose had a significantly negative correlation with serum $\mathrm{Mg}$ (Spearman's r=-0.384, $\mathrm{p}=0.001$ ). Similarly, these biomarkers were significantly higher ( $\mathrm{p}=0.033, \mathrm{p}=0.036, \mathrm{p}=0.003$, respectively) in patients with severe OSA than those with only mild/moderate symptoms. On the contrary, Zota et al. [26] reported no significant difference in fasting serum glucose between severe and moderate OSA groups.

\subsubsection{Trace minerals and heavy metals}

In addition to $\mathrm{Mg}$, Asker et al. [21] also assessed the serum levels of trace minerals (copper, iron, zinc, manganese, and cobalt) and heavy metals (lead and cadmium) in both OSA patients and non-apnoeic controls. The OSA group showed significantly higher levels of all these minerals ( $\mathrm{p}=0.002$ for manganese and $\mathrm{p}<0.001$ for the rest) except cadmium. $\mathrm{Mg}$ had significant positive Spearman's correlations $(p<0.001)$ with these trace 
minerals while correlated negatively with lead.

Since $\mathrm{Mg}$ is a physiological calcium $(\mathrm{Ca})$ antagonist, Çakır et al. [25] hypothesised that the $\mathrm{Ca} / \mathrm{Mg}$ ratio could be more informative than evaluating $\mathrm{Mg}$ or $\mathrm{Ca}$ alone in OSA patients. Their study found that even though OSA patients had numerically higher $\mathrm{Ca} / \mathrm{Mg}$ ratios than healthy controls, the difference is insignificant. In a subgroup analysis, the $\mathrm{Ca} / \mathrm{Mg}$ ratios were compared between the severe OSA patients and mild/moderate OSA patients, and the difference was statistically significant $(4.83 \pm 0.48$ vs. $4.51 \pm 0.39, \mathrm{p}=0.17)$.

\subsubsection{C-reactive protein, ischemia- modified albumin \& carotid intima- media thickness}

Karamanli et al. [23] evaluated the relationship between serum $\mathrm{Mg}$ levels and the inflammatory response in patients with OSA. In addition to showing that $\mathrm{Mg}$ levels were lower in patients with OSA, the study also showed that patients with OSA had substantially higher plasma C-reactive protein (CRP) concentrations than controls $(7.6 \pm 1.3$ $\mathrm{g} / \mathrm{dL}$ in OSA group with $\mathrm{N}=68,2.7 \pm 1.5 \mathrm{~g} / \mathrm{dL}$ in control group with $\mathrm{N}=30, \mathrm{p}<0.0001)$. The study showed a significant difference in the mean $\mathrm{Mg}$ and CRP levels based on patients AHI scores of $5-15$ and scores $\geq 30$ based on OSA severity but independent of BMI $(\mathrm{p}=0.001)$. Hence, serum $\mathrm{Mg}$ levels reduced depending on the presence of OSA and its severity, and low $\mathrm{Mg}$ levels are associated with higher levels of CRP concentrations.

$\mathrm{Xu}$ et al. [24] investigated whether the analysis of $\mathrm{Mg}$, high sensitivity C-reactive protein (hsCRP), and ischemia-modified albumin (IMA) concentrations can be used as a method of diagnosis for OSA. The study showed that patients with OSA $(n=33)$ had higher hsCRP concentrations than those without $\quad(\mathrm{n}=30) \quad(1.47 \pm 1.60 \quad \mathrm{mg} / \mathrm{L} \quad v s$. $0.97 \pm 1.22 \mathrm{mg} / \mathrm{L} ; \mathrm{p}<0.05)$. The study also showed that there was a significant correlation between serum IMA $(r=0.614$; $\mathrm{p}<0.001)$ and hsCRP $(\mathrm{r}=-.453 ; \mathrm{p}<0.001)$ levels and AHI concluding that patients with OSA have reduced $\mathrm{Mg}$ levels and higher serum hsCRP and IMA levels. Serum IMA also occurred at higher levels in participants with OSA than in the control group $(0.43$ \pm 0.09 absorbance units, $\mathrm{p}<0.05)$. These levels, however, were reversed by CPAP treatment interventions. Asker et al. [21] study also assessed CRP levels based on OSA diagnosis; the study showed patients with OSA ( $n=61)$ had higher levels of CRP compared to control groups $(n=36)$ (severe OSA: $0.52 \mathrm{mg} / \mathrm{dL}$ vs. control: $0.40 \mathrm{mg} / \mathrm{dL}$. The study showed that carotid intima-media thickness (CIMT), the test used to measure the carotid artery's inner two layers, was increased in OSA patients. This increase in CIMT was correlated with levels of cobalt, copper, iron, $\mathrm{Mg}$, and manganese.

\subsection{Quality assessment}

The quality assessment ratings and findings of the six included articles are summarised in Table 2. Supplementary 1 presents a more detailed version of the findings. Two studies were rated as poor quality of which, the poor rating of Asker et al. [21] was due to discrepancies in serum $\mathrm{Mg}$ unit reporting mentioned earlier. The study by Zota et al. [26] was also deemed unsatisfactory due to the ambiguity in the study population selection criteria. The report also offers no details for the length of the study and when the study was carried out. The diagnostic method of OSA also varied between participants as some were diagnosed using take-home sleep tests and others based on hospital overnight sleep test. Studies such as Cakir et al. [25] and Jaio et al. [22] were rated as fair as they had some unreported gaps such as justification in the sample size of participants, blinding of accessors or had low follow-up rates.

\section{Discussion}

Based on our findings, there is evidence suggesting that: (1) OSA patients have lower serum $\mathrm{Mg}$ levels than healthy controls, even 
though their serum Mg levels may still fall within the normal reference range. (2) OSA patients are at risk of $\mathrm{Mg}$ deficiency. (3) OSA severity appears to affect the serum $\mathrm{Mg}$ levels; the higher the AHI, the lower the serum Mg. (4) Serum Mg levels of OSA patients correlate with biomarkers including CRP, IMA and CIMT for cardiovascular disease risks. The serum $\mathrm{Mg}$ levels also potentially correlate with biomarkers for lipid profile, glucose metabolism, $\mathrm{Ca}$ and heavy metals.

Our results were consistent with studies that displayed serum $\mathrm{Mg}$ levels correlating with other metabolic, endocrine and cardiovascular disorders [27, 28, 29]. However, the direct relationship between these conditions, OSA, and serum $\mathrm{Mg}$ levels is complex and multifactorial. Factors suggested to impact serum $\mathrm{Mg}$ levels in OSA patients include oxidative stress, insufficient dietary intake, and impaired $\mathrm{Mg}$ regulation due to other comorbidities.

Sleep deprivation is a form of stress and can alter behavioural, physiological, and cellular functioning. In an animal study investigating the effect of $\mathrm{Mg}$ and sleep deprivation, Akanmu et al. [30] showed that sleep deprivation significantly $(\mathrm{p}<0.05)$ decreased the plasma levels of free $\mathrm{Mg} 2+$ and $\mathrm{Ca} 2+$. The study also identified sleep deprivation as a contributing factor to the loss of $\mathrm{Mg}$ and $\mathrm{Ca}$ electrolytes and the problems associated with the integrity of physiological system functions. Furthermore, intermittent nocturnal hypoxia was also significantly associated with oxidative stress, the increase in pro-inflammatory markers, and OSA, according to Orrù et al. [31].

In a recent clinical study of patients with type 2 diabetes, a condition often associated with OSA, hypomagnesaemia was seen to be a significant pathogenic factor that causes increased oxidative stress. Mg deficiency was seen to enhance oxidate stress marker and was shown to have a significant negative correlation with serum malondialdehyde, an indicator of oxidative stress [32].

Other studies have suggested that disturbances of trace mineral metabolism were due to oxidative stress and inflammatory response. OSA affects the absorption and circulating levels of these substances $[33,34$, 35]. Increased intestinal absorption or release during tissue damage may also contribute to the increased serum levels of trace minerals $[36,37]$. If the balance is disturbed, excessive trace minerals may induce oxidative stress, leading to a vicious circle that reinforces chronic inflammation. Elimination of heavy metals may not be achieved due to oxidative stress and inflammation, and this may explain the high levels of cadmium and lead in the setting of OSA [21]. Lead is a proinflammatory heavy metal that helps amplify oxidative stress and interferes with divalent cations such as $\mathrm{Mg}$ and may lead to reduced levels of serum Mg. Asker et al. [21] showed that OSA patients had higher levels of heavy metals and that $\mathrm{Mg}$ negatively correlated with lead. As $\mathrm{Mg}$ is a cofactor in more than 325 enzymes in the human body, disorders associated with $\mathrm{Mg}$ availability or function have been suggested to promote oxidative stress [38]. In OSA, nocturnal hypoxia was significantly associated with oxidative stress and the increase in pro-inflammatory markers [31]. This complex relationship between trace mineral metabolism, oxidative stress, and $\mathrm{Mg}$ levels in OSA warrants further investigation.

Mechanisms associated with impaired $\mathrm{Mg}$ regulation can be related to common diseases, which can be affected by dietary intake. Dietary analysis of 93 OSA patients by Bronkowska et al. [39] reported a low intake of high $\mathrm{Mg}$ foods. The patients had a mean $\mathrm{Mg}$ intake of only $194.0 \mathrm{mg}$ and did not meet the recommended dietary allowance of 280.0 $\mathrm{mg}$. The participants had slight deficiencies in $\mathrm{Mg}$ and other minerals such as calcium, zinc and iron. Notably, in this study, $75 \%$ of women and $91.9 \%$ of men received CPAP treatment which could help to increase $\mathrm{Mg}$ levels. Thus, the serum $\mathrm{Mg}$ levels in these 
patients could be lower without intervention. $\mathrm{Cao}$ et al. [40] investigated $\mathrm{Mg}$ intake and sleep disorder symptoms in adults $(\mathrm{n}=1487)$ using a food diary and sleep quality questionnaires. The study showed no associations between dietary $\mathrm{Mg}$ intake and daytime sleepiness nor night snoring in either gender. The study concluded that $\mathrm{Mg}$ supplementation might have long-term benefits in reducing the likelihood of daytime falling asleep in women. The lack of clinical diagnosis of sleep disorders and serum analysis of potential nutritional deficiencies in this study does impact the validity of these results and conclusions. Controlled, clinicalbased trials on the effect of $\mathrm{Mg}$ intake and sleep disorder conditions such as OSA can help investigate these links for more accurate findings.

A growing body of literature has shown a pat hological role for $\mathrm{Mg}$ deficiency. Ismail et al. [29] reviewed 221 peer-reviewed studies published from 1990 to April 2015 and found the association of $\mathrm{Mg}$ deficiency with increased risk and prevalence in multiple conditions, including cardiovascular pathology, electrolyte disorders, hypertension, endocrine and metabolic disorders, muscular, neurological disorders and even some cancers such as colorectal cancer. This inverse relationship was seen irrespective of the methods used to assess magnesium body stores. Similarly, the review found 79 studies where Mg deficiency was found to predict adverse events, and a reduced risk of pathology was seen when supplementation was introduced.

As with all research, this review has limitations. The strict inclusion criteria used in the meta-analysis conducted allowed for a small number of studies. They are not likely to represent OSA patients in general, and the results must be interpreted with cautions. Also, the review included only publications in English, and there may be findings from other languages that we did not include. An epidemiology study investigating the serum $\mathrm{Mg}$ levels in OSA patients is warranted. Such a study can help provide more accurate data for drawing definitive conclusions.

Our research has identified a gap in the understanding of the correlation between $\mathrm{Mg}$ serum levels and OSA. There are also insufficient studies investigating the definitive role and use of $\mathrm{Mg}$ supplement in the management of OSA. Further research investigating the link between $\mathrm{Mg}$ levels, OSA, and systemic inflammatory markers is worthwhile as correcting $\mathrm{Mg}$ deficiency through diet or supplementation can be an affordable treatment option addressing both OSA and its chronic comorbidities.

\section{Conclusion}

The link between $\mathrm{Mg}$ and OSA remains poorly understood, with some studies showing a potentially significant relationship between OSA severity and serum Mg levels. This study is the first systematic review and meta-analysis of its kind, and it provides evidence that OSA patients are at risk of $\mathrm{Mg}$ deficiency. An improvement in serum $\mathrm{Mg}$ levels of OSA patients after intervention presents a promising area of research for the overall management of both $\mathrm{Mg}$ deficiency and OSA. More research, public health awareness, and emphases on the importance of dietary $\mathrm{Mg}$ is needed for all age groups to help reduce its potential insufficiency and the associated risks.

\section{Funding}

This research received no specific grant from any funding agency in the public, commercial, or not-for-profit sectors. The authors declare no conflict of interest.

\section{Conflicts of interest}

The authors declare that they have no known competing financial interests or personal relationships that could have influenced the work reported in this paper. 


\section{Authors' contributions}

The first two authors contributed equally to this work. All authors reviewed and substantially contributed to the final version of the manuscript.

\section{References}

[1] Osman AM, Carter SG, Carberry JC, Eckert DJ. Obstructive sleep apnea: current perspectives. Nat Sci Sleep 2018;10:21-34. https://doi.org/10.2147/NSS.S124657.

[2] Spicuzza L, Caruso D, Di Maria G. Obstructive sleep apnoea syndrome and its management. Ther Adv Chronic Dis 2015;6:273-85. https://doi.org/10.1177/204062231559 0318.

[3] Stansbury RC, Strollo PJ. Clinical manifestations of sleep apnea. J Thorac Dis 2015;7:E298-310. https://doi.org/10.3978/j.issn.20721439.2015.09.13.

[4] Schwalfenberg GK, Genuis SJ. The importance of magnesium in clinical healthcare. Scientifica (Cairo) 2017;2017:4179326.

https://doi.org/10.1155/2017/4179326.

[5] Romani AMP. Magnesium in health and disease. In: Sigel A, Sigel H, Sigel $\mathrm{R}$, editors. Interrelat. between Essent. Met. Ions Hum. Dis. Met. Ions Life Sci. vol 13, Dordrecht: Springer; 2013, p. 49-79. https://doi.org/10.1007/97894-007-7500-8_3.

[6] Jahnen-Dechent W, Ketteler M. Magnesium basics. Clin Kidney $\mathrm{J}$ 2012;5:i3-14.

https://doi.org/10.1093/ndtplus/sfr163.

[7] King DE, Mainous AG, Geesey ME, Egan BM, Rehman S. Magnesium supplement intake and C-reactive protein levels in adults. Nutr Res
2006;26:193-6.

https://doi.org/https://doi.org/10.1016/ j.nutres.2006.05.001.

[8] Australian Bureau of Statistics. Australian Health Survey: Usual Nutrient Intakes, 2011-12 (Cat. No 4364.0.55.008) 2015.

[9] DiNicolantonio JJ, O'Keefe JH, Wilson W. Subclinical magnesium deficiency: a principal driver of cardiovascular disease and a public health crisis. Open Hear 2018;5:e000668-e000668. https://doi.org/10.1136/openhrt-2017000668.

[10] Costello RB, Nielsen F. Interpreting magnesium status to enhance clinical care: key indicators. Curr Opin Clin Nutr Metab Care 2017;20:504-11. https://doi.org/10.1097/MCO.0000000 000000410.

[11] Costello RB, Elin RJ, Rosanoff A, Wallace TC, Guerrero-Romero F, Hruby A, et al. Perspective: The case for an evidence-based reference interval for serum magnesium: The time has come. Adv Nutr 2016;7:97793.

https://doi.org/10.3945/an.116.012765

[12] Tangvoraphonkchai K, Davenport A. Magnesium and cardiovascular disease. Adv Chronic Kidney Dis 2018;25:251-60.

https://doi.org/10.1053/j.ackd.2018.02 .010 .

[13] Ju S-Y, Choi W-S, Ock S-M, Kim CM, Kim D-H. Dietary magnesium intake and metabolic syndrome in the adult population: dose-response metaanalysis and meta-regression. Nutrients 2014;6:6005-19. https://doi.org/10.3390/nu6126005.

[14] Barbagallo M, Dominguez LJ. 
Magnesium and type 2 diabetes. World J Diabetes 2015;6:1152-7. https://doi.org/10.4239/wjd.v6.i10.115 2.

[15] Hassan SAU, Ahmed I, Nasrullah A, Haq S, Ghazanfar H, Sheikh AB, et al. Comparison of serum magnesium levels in overweight and obese children and normal weight children. Cureus 2017;9:e1607-e1607. https://doi.org/10.7759/cureus.1607.

[16] Hein M, Lanquart J-P, Loas G, Hubain $\mathrm{P}$, Linkowski P. Prevalence and risk factors of moderate to severe obstructive sleep apnea syndrome in insomnia sufferers: a study on 1311 subjects. Respir Res 2017;18:135. https://doi.org/10.1186/s12931-0170616-8.

[17] Yacoub M, Youssef I, Salifu MO, McFarlane SI. Cardiovascular Disease Risk in Obstructive Sleep apnea: An Update. J Sleep Disord Ther 2017;7:283.

https://doi.org/10.4172/21670277.1000283.

[18] Al Alawi AM, Majoni SW, Falhammar H. Magnesium and human health: perspectives and research directions. Int J Endocrinol 2018;2018:9041694. https://doi.org/10.1155/2018/9041694.

[19] Drahota A, Beller E. RevMan Calculator. Cochrane Train n.d. https://training.cochrane.org/resource/ revman-calculator (accessed December 8, 2020).

[20] National Institutes of Health. Quality Assessment Tool for Observational Cohort and Cross-Sectional Studies n.d. https://www.nhlbi.nih.gov/healthtopics/study-quality-assessment-tools (accessed December 8, 2020).

[21] Asker S, Asker M, Yeltekin AC, Aslan M, Demir H. Serum levels of trace minerals and heavy metals in severe obstructive sleep apnea patients: correlates and clinical implications. Sleep Breath 2015;19:547-52. https://doi.org/10.1007/s11325-0141045-2.

[22] Jiao X, Zou J, Zhang P, Yu H, Di J, Han $X$, et al. Roux-en-Y Gastric Bypass Surgery on Obstructive Sleep Apnea-Hypopnea Syndrome: Factors Associated with Postoperative Efficacy. Obes Surg 2016;26:2924-30. https://doi.org/10.1007/s11695-0162209-x.

[23] Karamanli H, Kizilirmak D, Akgedik R, Bilgi M. Serum levels of magnesium and their relationship with CRP in patients with OSA. Sleep Breath 2017;21:549-56. https://doi.org/10.1007/s11325-0161402-4.

[24] Xu Q, Du J, Ling X, Lu Y. Evaluation of MIh scoring system in diagnosis of obstructive sleep apnea syndrome. Med Sci Monit Int Med J Exp Clin Res 2017;23:4715-22.

https://doi.org/10.12659/msm.904087.

[25] Çakır I, Uluhan M. Evaluation of metabolic risk markers: Calcium/ magnesium ratio, lipoproteins and insulin resistance in patients with obstructive sleep apnea syndrome. Erciyes Med J 2018;40:131-5. https://doi.org/10.5152/etd.2017.0109.

[26] Zota IM, Sascau R, Statescu C, Roca M, Boisteanu D, Constantin MML, et al. Arterial stiffness in moderate-severe obstructive sleep apnea. Rom J Cardiol Vol 2019;29.

[27] Rodrigues AK, Melo AE, Domingueti CP. Association between reduced serum levels of magnesium and the presence of poor glycemic control and complications in type 1 diabetes mellitus: A systematic review and 
meta-analysis. Diabetes \& Metabolic Syndrome: Clinical Research \& Reviews. 2020 Mar 1;14(2):127-34.

[28] Severino P, Netti L, Mariani MV, Maraone A, D'Amato A, Scarpati R, Infusino F, Pucci M, Lavalle C, Maestrini V, Mancone M. Prevention of cardiovascular disease: screening for magnesium deficiency. Cardiology research and practice. 2019 May $2 ; 2019$.

[29] Ismail AA, Ismail NA. Magnesium: A mineral essential for health yet generally underestimated or even ignored. J. Nutr. Food Sci. 2016;6(2).

[30] Akanmu MA, Meludu SC, Honda K. Effects of 6-hour total sleep deprivation on plasma magnesium and calcium levels in rats. Sleep and Biological Rhythms. 2003 Mar;1(2):97-100.

[31] Orrù G, Storari M, Scano A, Piras V, Taibi R, Viscuso D. Obstructive Sleep Apnea, oxidative stress, inflammation and endothelial dysfunction-an overview of predictive laboratory biomarkers. European Review for Medical and Pharmacological Sciences. 2020 Jun 1;24(12):6939-48.

[32] Kaliaperumal R, Venkatachalam R, Nagarajan P, Sabapathy SK. Association of Serum Magnesium with Oxidative Stress in the Pathogenesis of Diabetic Cataract. Biological Trace Element Research. 2020 Oct 9:1-5.

[33] Volna J, Kemlink D, Kalousova M, Vavrova J, Majerova V, Mestek O, Švarcová J, Šonka K, Zima T. Biochemical oxidative stress-related markers in patients with obstructive sleep apnea. Medical science monitor: international medical journal of experimental and clinical research. 2011;17(9):CR491.
[34] Tapiero H, Townsend DÁ, Tew KD. Trace elements in human physiology and pathology. Copper. Biomedicine \& pharmacotherapy. 2003 Nov 1;57(9):386-98.

[35] Kocyigit AB, Armutcu F, Gurel A, Ermis B. Alterations in plasma essential trace elements selenium, manganese, zinc, copper, and iron concentrations and the possible role of these elements on oxidative status in patients with childhood asthma. Biological trace element research. 2004 Jan;97(1):31-41.

[36] O'connor JM. Trace elements and DNA damage. Biochemical Society Transactions. 2001 May;29(2):354-8.

[37] Krachler M, Rossipal E, Micetic-Turk D. Concentrations of trace elements in sera of newborns, young infants, and adults. Biological trace element research. 1999 May;68(2):121-35.

[38] Wyparło-Wszelaki M, Wąsik M, Machoń-Grecka A, Kasperczyk A, Bellanti F, Kasperczyk S, Dobrakowski M. Blood magnesium level and selected oxidative stress indices in lead-exposed workers. Biological trace element research. $2021 \mathrm{Feb} ; 199(2): 465-72$.

[39] Bronkowska M, Gołecki M, Słomian J, Mikołajczak J, Kosacka M, Porębska I, Jankowska R, Biernat J. Evaluation of vitamin and mineral intake in the daily food rations of overweight and obese patients diagnosed with obstructive sleep apnea. Adv Clin Exp Med. 2010 Jan 1;19:607-17.

[40] Cao Y, Zhen S, Taylor AW, Appleton S, Atlantis E, Shi Z. Magnesium intake and sleep disorder symptoms: Findings from the Jiangsu Nutrition Study of Chinese adults at five-year 
follow-up. Nutrients. $\quad 2018$

Oct;10(10):1354. 
Table 1. A summary of study characteristics of the included studies.

\begin{tabular}{|c|c|c|c|c|c|}
\hline Study & $\begin{array}{l}\text { Study } \\
\text { Design }\end{array}$ & Participants & Study objective & $\begin{array}{c}\text { Mean serum Mg } \\
\text { (mg/dL) }\end{array}$ & Other relevant findings \\
\hline $\begin{array}{l}\text { Asker (2015) } \\
\text { Turkey [21] }\end{array}$ & $\begin{array}{l}\text { Cross- } \\
\text { sectional case- } \\
\text { control study }\end{array}$ & $\begin{array}{l}\text { OSA: patients diagnosed } \\
\text { with severe OSA ( } \mathrm{AHI} \geq 30 \text { ), } \\
\mathrm{N}=61 \text {. Male/Female: } \\
\text { 42/19. Mean age: } 48.2 \pm \\
9.1 . \\
\text { Control: healthy } \\
\text { volunteers, } \mathrm{N}=36 . \\
\text { Male/Female: } 11 / 25 \text {. } \\
\text { Mean age: } 46.9 \pm 10.2 \text {. }\end{array}$ & $\begin{array}{l}\text { Evaluation of serum levels } \\
\text { of trace minerals and heavy } \\
\text { metals in severe OSA } \\
\text { patients before any } \\
\text { therapeutic intervention. }\end{array}$ & $\begin{array}{l}\text { OSA: } 0.01423 \pm \\
0.00488 \\
\text { Control: } 0.0112 \pm \\
0.00722 \\
\text { OSA }>\text { Control }(p \\
<0.001)\end{array}$ & $\begin{array}{l}\text { The OSA group had significantly higher } \\
\text { cholesterol, triglycerides, trace minerals, } \\
\text { heavy minerals, and CIMT compared to the } \\
\text { control ( } \mathrm{p}<0.005 \text { for all). } \\
\text { CIMT and triglycerides were positively } \\
\text { correlated with } \mathrm{Mg} \text {. HDL was negatively } \\
\text { correlated with } \mathrm{Mg} \text {. }\end{array}$ \\
\hline $\begin{array}{l}\text { Jiao (2016) China } \\
\text { [22] }\end{array}$ & $\begin{array}{l}\text { Case-control } \\
\text { follow up } \\
\text { observational } \\
\text { study }\end{array}$ & $\begin{array}{l}\text { OSA patients ( } \mathrm{AHI} \geq 5 \text { ) with } \\
\text { obesity and type } 2 \\
\text { diabetes mellitus receiving } \\
\text { RYGB surgery, } \mathrm{N}=39 . \\
\text { Male/Female: } 15 / 24 \\
\text { Mean age: } 44.20 \pm 8.95 \\
\text { (Males); } 50.50 \pm 12.29 \\
\text { (Females). }\end{array}$ & $\begin{array}{l}\text { Assessing the efficacy of } \\
\text { RYGB surgery on patients } \\
\text { with OSA using PSG and } \\
\text { biochemical tests (including } \\
\text { Mg levels), pre and post- } \\
\text { surgery. } \\
\text { Study duration: } 6-12 \text { months } \\
\text { post-intervention. }\end{array}$ & $\begin{array}{l}\text { Preoperative: } \\
2.04 \pm 0.17 \\
\text { Postoperative: } \\
2.19 \pm 0.17 \\
\text { Post }>\text { Pre }(p<0.001)\end{array}$ & $\begin{array}{l}\text { RYGB surgery significantly lowered the AHI } \\
\text { and BMI in OSA patients. Postoperative } \\
\text { blood Mg levels were significantly increased } \\
\text { in OSA patients when compared to at the } \\
\text { time of diagnosis ( } p<0.05) . \mathrm{Mg} \text { was not } \\
\text { correlated with the improvement in AHI. }\end{array}$ \\
\hline $\begin{array}{l}\text { Karamanli (2017) } \\
\text { Turkey [23] }\end{array}$ & $\begin{array}{l}\text { Retrospective } \\
\text { cross- } \\
\text { sectional } \\
\text { study }\end{array}$ & $\begin{array}{l}\text { OSA: patients recently } \\
\text { diagnosed with OSA (AHI } \\
\geq 5 \text { ), } N=68 \text {. Male/Female: } \\
46 / 22 \text {. } \\
\text { Control: healthy } \\
\text { volunteers, } N=30 \text {. } \\
\text { Male/Female: } 14 / 16 \text {. }\end{array}$ & $\begin{array}{l}\text { To evaluate the relationship } \\
\text { between serum levels of Mg } \\
\text { and the inflammatory } \\
\text { response (CRP) in patients } \\
\text { with newly diagnosed OSA. }\end{array}$ & $\begin{array}{l}\text { OSA: } 1.71 \pm 0.21 \\
\text { Control: } 2.19 \pm 0.36 \\
\text { OSA }<\text { Control }(p \\
<0.0001)\end{array}$ & $\begin{array}{l}\text { Mg levels were lower in OSA patients than } \\
\text { those in controls. Those with severe OSA } \\
\text { also had significantly lower Mg ( } p=0.03 \text { ) than } \\
\text { those with mild OSA. OSA group has a } \\
\text { significantly higher CRP. A significant } \\
\text { negative correlation was observed between } \\
\text { Mg and CRP levels ( } p<0.0001) \text {. }\end{array}$ \\
\hline
\end{tabular}




\begin{tabular}{|c|c|c|c|c|c|}
\hline $\begin{array}{l}\text { Xu (2017) China } \\
\text { [24] }\end{array}$ & $\begin{array}{l}\text { Case-control } \\
\text { study with } \\
\text { subgroup } \\
\text { follow-up }\end{array}$ & $\begin{array}{l}\text { OSA: patients diagnosed } \\
\text { with OSA (AHI } \geq 5), \mathrm{N}=33 \text {. } \\
\text { Male/Female: } 23 / 10 \text {. } \\
\text { Mean age: } 51.6 \pm 9.8 \text {. } \\
\text { Control: healthy } \\
\text { volunteers, } N=30 \text {. } \\
\text { Male/Female: } 21 / 9 . \text { Mean } \\
\text { age: } 52.1 \pm 10.9 \text {. }\end{array}$ & $\begin{array}{l}\text { Investigating } \mathrm{Mg} \text {, hsCRP, } \\
\text { and IMA as a non-invasive } \\
\text { diagnosis method for OSA. } \\
\text { Participants followed up } \\
\text { after } 3 \text { months of CPAP } \\
\text { treatment. }\end{array}$ & $\begin{array}{l}\text { OSA: } 1.71 \pm 0.21 \\
\text { Control: } 2.19 \pm 0.36 \\
\text { OSA < Control } \\
(p=0.021) \\
\text { Post-CPAP: } 2.02 \pm 0.25 \\
(\mathrm{~N}=22 \text { only) } \\
\text { Post }>\text { Baseline ( } p \\
<0.001)\end{array}$ & $\begin{array}{l}\text { OSA patients had significantly higher levels } \\
\text { of hsCRP and IMA and significantly lower Mg } \\
\text { compared to control ( } \mathrm{p}<0.05 \text { for all). Mg, } \\
\text { hsCRP, and IMA were used in a novel model } \\
\text { to diagnose OSA with AUROC of } 0.93 \text { ( } 0.83- \\
0.98 \text { ). } \\
\text { OSA patients showed significant } \\
\text { improvements in Mg, hSCRP, and IMA after } \\
\text { CPAP treatment. }\end{array}$ \\
\hline $\begin{array}{l}\text { Cakir (2018) } \\
\text { Turkey [25] }\end{array}$ & $\begin{array}{l}\text { Clinical case- } \\
\text { control study }\end{array}$ & $\begin{array}{l}\text { OSA: Patients recently } \\
\text { diagnosed with OSA (AHI } \\
\geq 5 \text { ), } \mathrm{N}=70 \text { ( } 55 \text { severe, } 11 \\
\text { moderate and } 4 \text { mild). } \\
\text { Male/Female: } 70 / 0 \text {. } \\
\text { Mean age: } 47.57 \pm 12.15 \text {. } \\
\text { Control: non-apnoeic } \\
\text { individuals (AHI <5), } \mathrm{N}=30 \text {. } \\
\text { Male/Female: } 30 / 0 . \\
\text { Mean age: } 43.23 \pm 10.5 \text {. }\end{array}$ & $\begin{array}{l}\text { Comparing OSA patients' } \\
\text { metabolic markers (BMI, } \\
\text { PSG, insulin sensitivity- } \\
\text { resistance markers, lipid } \\
\text { profiles) and mineral levels } \\
\text { with those of control } \\
\text { subjects. }\end{array}$ & $\begin{array}{l}\text { OSA: } 2.0 \pm 0.12 \\
\text { Control: } 2.04 \pm 0.19\end{array}$ & $\begin{array}{l}\text { There were no statistically significant } \\
\text { differences in serum } \mathrm{Mg} \text {, Ca, and } \mathrm{Ca} / \mathrm{Mg} \\
\text { ratios between OSA patients and controls. } \\
\text { Fasting glucose and insulin levels were } \\
\text { significantly higher in the OSA group ( } \mathrm{p}<0.05 \\
\text { for all). Fasting glucose levels were } \\
\text { correlated with } \mathrm{Ca}, \mathrm{Mg} \text {, and } \mathrm{Ca} / \mathrm{Mg} \text { ratios. } \\
\text { Severe OSAS patients had significantly higher } \\
\mathrm{Ca} / \mathrm{Mg} \text { ratios than mild/moderate groups } \\
(p=0.017) \text {. }\end{array}$ \\
\hline $\begin{array}{l}\text { Zota (2019) } \\
\text { Romania [26] }\end{array}$ & $\begin{array}{l}\text { Cross- } \\
\text { sectional, } \\
\text { single cohort } \\
\text { study }\end{array}$ & $\begin{array}{l}\text { OSA: patients recently } \\
\text { diagnosed with moderate- } \\
\text { severe OSA (AHI } \geq 5), N=41 \\
\text { ( } 23 \text { severe and } 18 \\
\text { moderate/mild). Mean } \\
\text { age: } 55.83 \\
\text { (moderate/mild), } 57.34 \\
\text { (severe). }\end{array}$ & $\begin{array}{l}\text { Assessed the relationship } \\
\text { between OSA severity, } \\
\text { arterial stiffness and clinic- } \\
\text { biological parameters in } \\
\text { moderate-severe OSA } \\
\text { patients prior to the use of } \\
\text { CPAP therapy. }\end{array}$ & $\begin{array}{l}\text { Moderate: } 2.09 \\
\text { Severe: } 1.9 \\
\text { SD not reported. } \\
\text { Between-group } \Delta \text { not } \\
\text { significant with } p \\
=0.1\end{array}$ & $\begin{array}{l}\text { No significant difference was found between } \\
\text { severe and moderate groups in Mg levels. } \\
\text { ESR was significantly higher in the severe } \\
\text { group ( } p=0.012 \text { ). Inflammation markers } \\
\text { (CRP \& ESR) were correlated with OSA } \\
\text { severity. Mg was negatively correlated with } \\
\text { PWV, which measured arterial stiffness. }\end{array}$ \\
\hline
\end{tabular}

Legend: $\mathrm{AHI}$, apnoea-hypopnoea index; AUROC, area under the receiver operating characteristics; BMI, body mass index; Ca, calcium; CPAP, continuous positive airway pressure; CRP, C-reactive protein; CIMT, carotid intima-media thickness; ESR, erythrocyte sedimentation rate; HDL, high-density lipoproteins; hsCRP, high sensitivity CRP; IMA, ischemia-modified albumin; Mg, magnesium; OSA, obstructive sleep apnoea; PSG, polysomnography; PWV, pulse wave velocity; RYGB, Roux-en-Y gastric bypass; SD, standard deviation. 
Table 2. Summary of study quality assement ratings

\begin{tabular}{|c|c|c|c|c|c|c|c|}
\hline $\begin{array}{l}\text { Criteria for Quality Assessment for Case-Control } \\
\text { Studies }\end{array}$ & $\begin{array}{c}\text { Asker et al. } \\
2015\end{array}$ & $\begin{array}{l}\text { Karamanli } \\
\text { et al. } 2017\end{array}$ & $\begin{array}{c}\text { Xu et al. } \\
2017\end{array}$ & $\begin{array}{c}\text { Cakir et al. } \\
2018\end{array}$ & $\begin{array}{l}\text { Zota et al. } \\
2019\end{array}$ & $\begin{array}{c}\text { Criteria for Quality Assessment for } \\
\text { Observational Cohort and Cross-Sectional } \\
\text { Studies }\end{array}$ & $\begin{array}{c}\text { Jaio et al. } \\
2016\end{array}$ \\
\hline Research question and/or objective & & & & & & Research question and/or objective & \\
\hline Study population specification & & & & & & Study population specification & \\
\hline Sample size justification & & & & & & Participation rate eligiblity & \\
\hline Controls selected and recruitment & & & & & & Subject selection and inclusion and exclusion criteria & \\
\hline Inclusion and exclusion criteria & & & & & & Sample size & \\
\hline Cases differentiation & & & & & & Analysis measures & \\
\hline Selection of cases and/or controls & & & & & & Timeframe for exposure and outcome & \\
\hline Concurrent controls & & & & & & Exposure measures & \\
\hline Exposure/risk & & & & & & Independent variables measures & \\
\hline Measures of exposure/risk & & & & & & Exposure(s) assessment & \\
\hline Subjective assessment & & & & & & Outcome measures & \\
\hline \multirow[t]{3}{*}{ Statistical analysis } & & & & & & Outcome assessors blinded & \\
\hline & & & & & & Follow-up after baseline & \\
\hline & & & & & & Statistical analysis & \\
\hline Quality Rating (Good, Fair, or Poor) & Poor & Good & Good & Fair & Poor & Quality Rating (Good, Fair, or Poor) & Fair \\
\hline
\end{tabular}

Legend: Green: Yes; Red: No; Gray: Not Applicable; Yellow: Not Reported or Cannot Determine. 

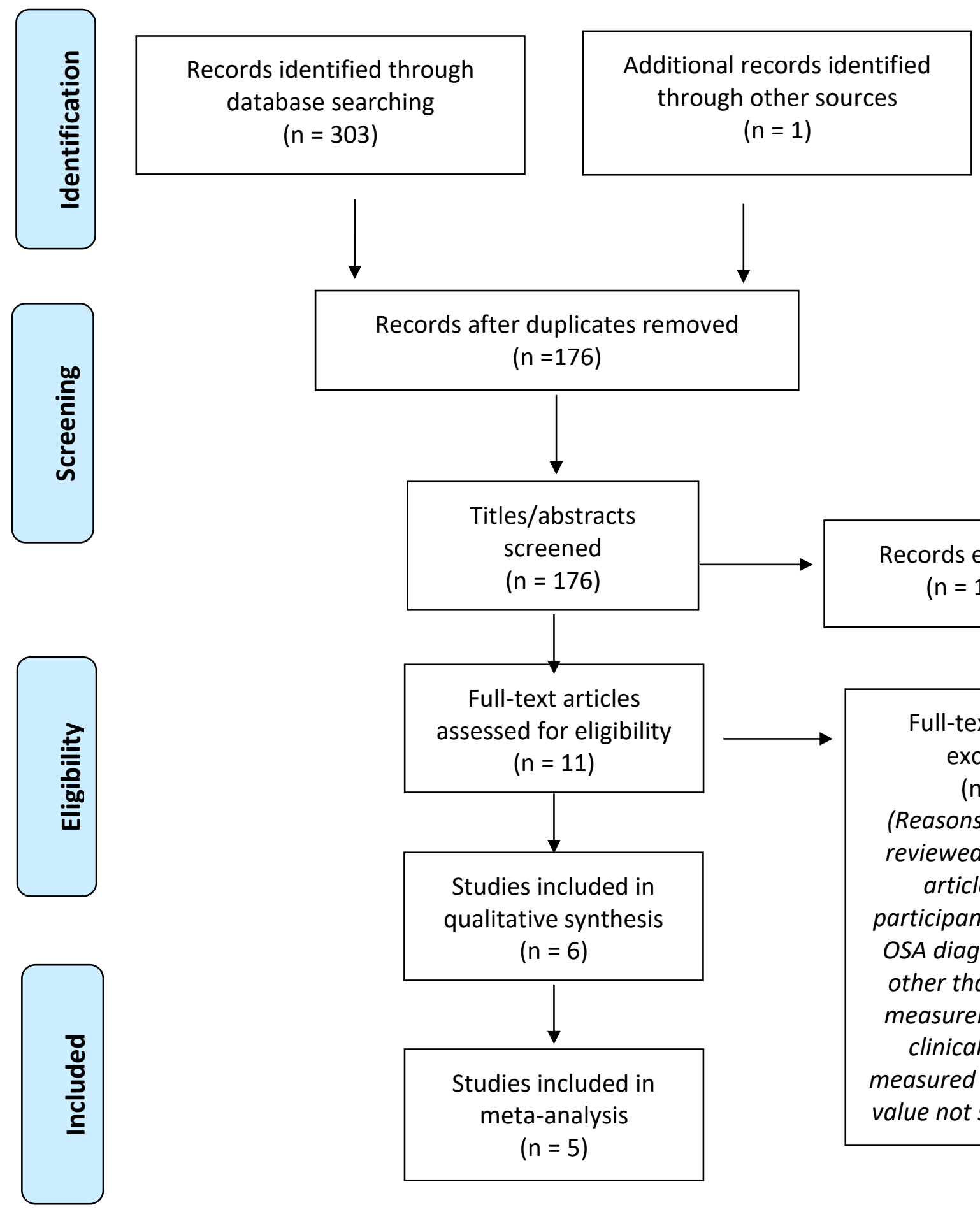
Records excluded $(n=165)$

Studies included in qualitative synthesis $(n=6)$

Full-text articles assessed for eligibility $(n=11)$

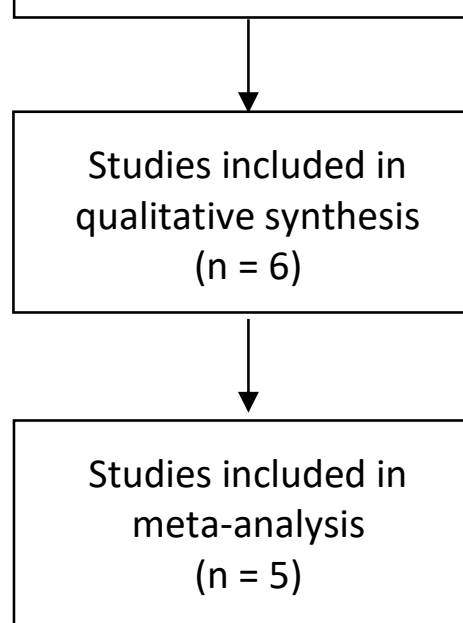
Full-text articles excluded $(\mathrm{n}=5)$

(Reasons: Non- peer reviewed, discussion article, single participant case study; OSA diagnosed using other than specified measurements, nonclinical trial, $\mathrm{Mg}$ measured in nutritional value not serum levels)

Figure 1. Flow diagram of study selection 
Figure 2. Forest plots -Meta-analyses of the standardised mean difference of the effects of OSA on serum Mg.

(a) All studies

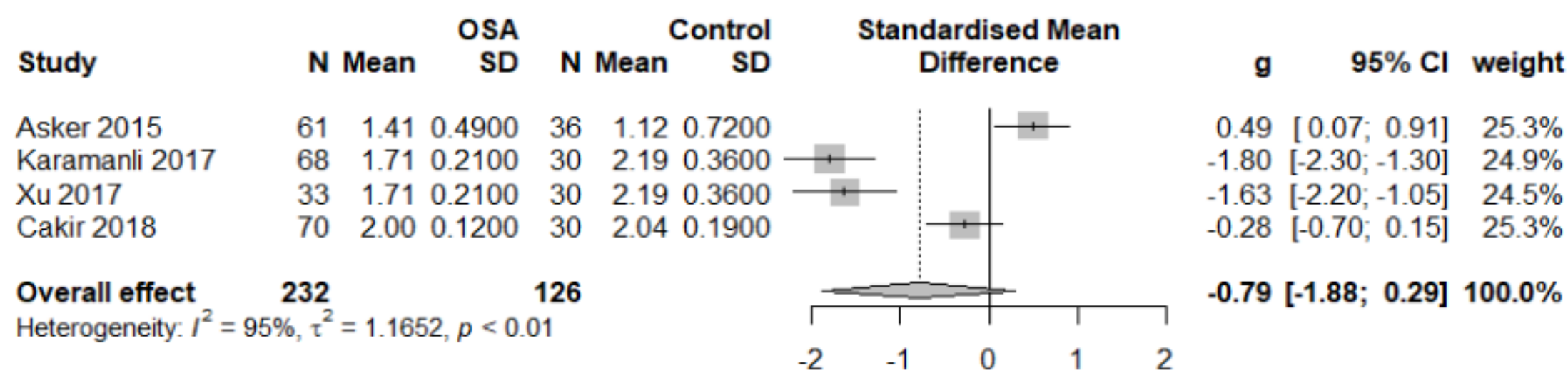

(b) Excluding Asker 2015

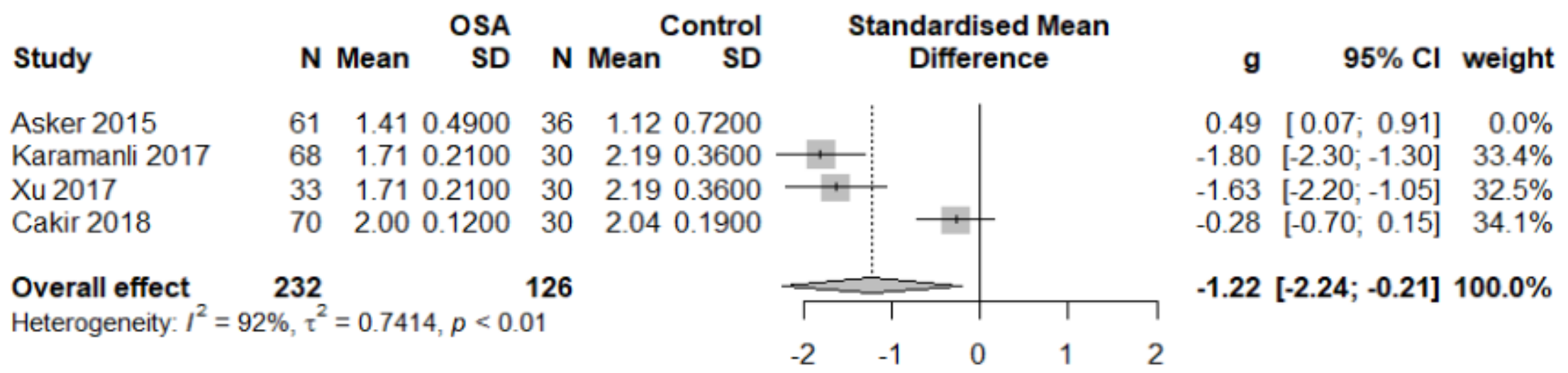


Figure 3. Forest plot: A meta-analysis of the mean serum Mg levels of included studies excluding Asker, 2015 (MRAW = untransformed mean).

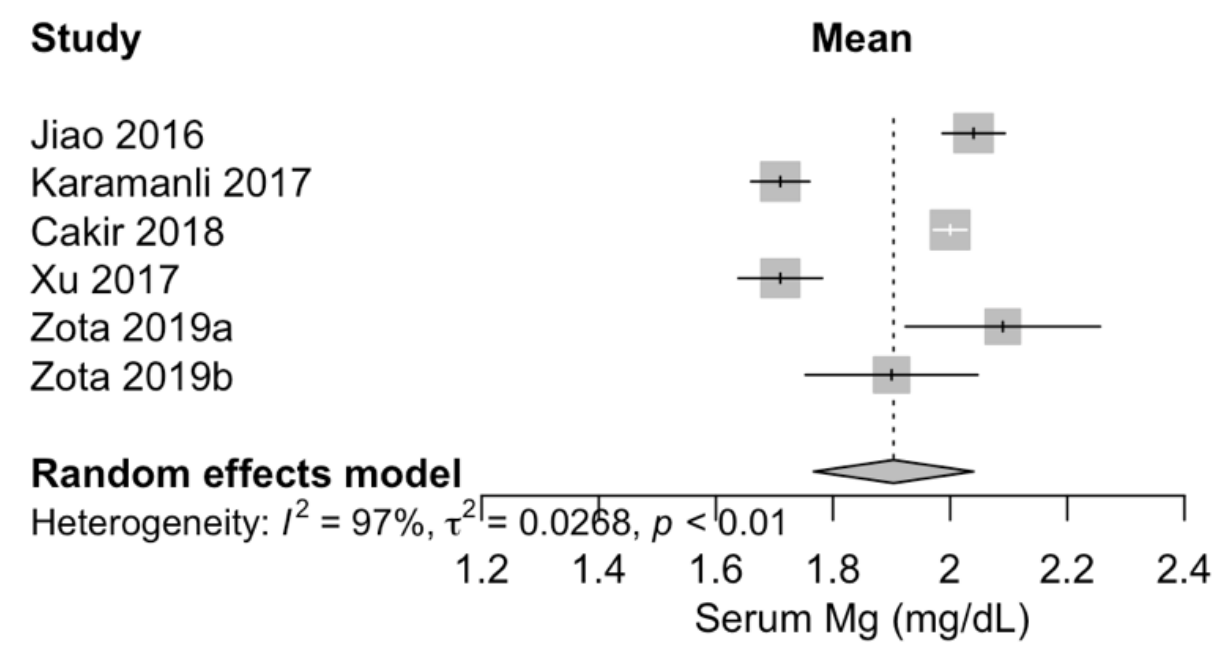

Karamanli 2017

Cakir 2018

Xu 2017

Zota 2019a

Zota 2019b

Random effects model

Heterogeneity: $I^{2}=97 \%, \tau^{2}=0.0268, p<0.01$

Serum $\mathrm{Mg}(\mathrm{mg} / \mathrm{dL})$

\section{MRAW 95\%-Cl Weight}

$2.04[1.99 ; 2.09] \quad 17.7 \%$

$1.71[1.66 ; 1.76] \quad 17.7 \%$

$2.00[1.97 ; 2.03] \quad 18.0 \%$

$1.71[1.64 ; 1.78] \quad 17.3 \%$

$2.09[1.92 ; 2.26] \quad 14.3 \%$

$1.90[1.75 ; 2.05] \quad 15.0 \%$

$1.90[1.77 ; 2.04] 100.0 \%$ 